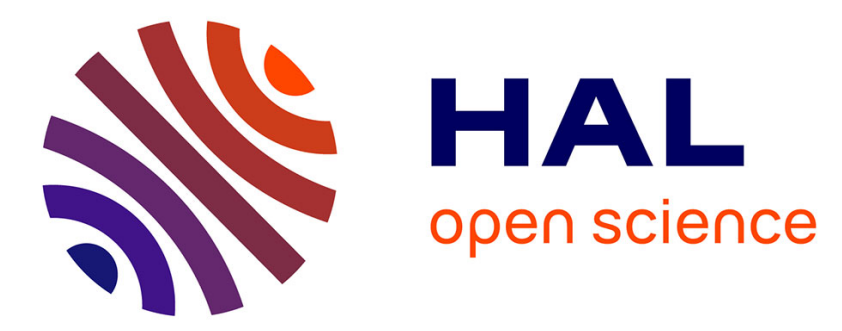

\title{
Synthesis and characterization of new membranes deriving from sulfonated polyethersulfone for PEMFC applications
}

\author{
Walid Mabrouk, Lionel Ogier, Cyrille Sollogoub, Serge Vidal, Fatma \\ Matoussi, Jean François Fauvarque
}

\section{To cite this version:}

Walid Mabrouk, Lionel Ogier, Cyrille Sollogoub, Serge Vidal, Fatma Matoussi, et al.. Synthesis and characterization of new membranes deriving from sulfonated polyethersulfone for PEMFC applications. Desalination and Water Treatment, 2015, 56 (10), pp.2637-2645. 10.1080/19443994.2015.1024939 . hal-02568809

\section{HAL Id: hal-02568809 \\ https://hal.science/hal-02568809}

Submitted on 10 May 2020

HAL is a multi-disciplinary open access archive for the deposit and dissemination of scientific research documents, whether they are published or not. The documents may come from teaching and research institutions in France or abroad, or from public or private research centers.
L'archive ouverte pluridisciplinaire HAL, est destinée au dépôt et à la diffusion de documents scientifiques de niveau recherche, publiés ou non, émanant des établissements d'enseignement et de recherche français ou étrangers, des laboratoires publics ou privés. 


\title{
Synthesis and characterization of new membranes deriving from sulfonated polyethersulfone for PEMFC applications
}

\author{
W. Mabrouk ${ }^{\mathrm{a}, \mathrm{b}, \mathrm{c}}$, L. Ogier ${ }^{\mathrm{d}}$, C. Sollogoub ${ }^{\mathrm{c}}$, S. Vidal ${ }^{\mathrm{d}}$, F. Matoussi ${ }^{\mathrm{b}}$, J.F. Fauvarque ${ }^{\mathrm{e}, *}$ \\ ${ }^{a}$ Faculty of Sciences, Department of Chemistry, University of El Manar, 1092 Tunis, Tunisia, Tel. +216533 04324 ; \\ email: mabrou_walid@yahoo.fr \\ ${ }^{b}$ Department of Chemical and Biological Engineering, INSAT, University of Carthage, 1080 Tunis, Tunisia, Tel. +216 96555088 ; \\ email: matoussif@yahoo.fr (F. Matoussi) \\ ${ }^{c}$ PIMM Laboratory, UMR 8006, ENSAM/CNRS/CNAM, 151, Boulevard de l'Hopital, 75013 Paris, France, Tel. +33 620 535908 ; \\ email: cyrille.sollogoub@cnam.fr (C. Sollogoub) \\ ${ }^{d}$ ERAS Labo, 222 RN 90, St Nazaire Les Eymes, Grenoble 38330, France, Tel. +33476 520 454; Fax: +33 476521753 ; \\ email: eras.labo@wanadoo.fr (S.Vidal) \\ ${ }^{e}$ Industrial Materials, Metallic, Polymeric E Ceramic, Electrochemistry Laboratory, CNAM, 2, rue Conté, 75003 Paris, France, \\ Tel. +33 140272 420; email: jean-francois.fauvarque@cnam.fr
}

\begin{abstract}
Two new types of proton exchange membranes used in proton exchange membrane fuel cell (PEMFC) were synthesized from sulfochlorinated polyethersulfone (PES (polyarylethersulfone)- $\mathrm{SO}_{2} \mathrm{Cl}$ ). One, called S-PESB, was obtained by grafting butylphenol in an amount of 0.3 equivalent per monomer unit. The second (S-PESTD) was prepared by cross-linking with 0.1 equivalent of 4,7,10-trioxa-1,13-tridecandiamine. Analysis of thermal properties (thermogravimetric analysis and DSA) and mechanical testing (dynamical and thermomechanical analysis) of the two membranes showed a significant improvement in comparison with unmodified polyethersulfone sulfonic acid (S-PES). Thus, a significant lowering of the glass transition temperature was observed. In addition, a comparative study carried out with the commercial Nafion $^{\mathbb{B}}$ membrane gave very similar values of ionic conductivity and a high selectivity of proton transport. A preliminary electrochemical study of membrane/electrode assembly has shown that the elaborated membranes are promising in PEMFC application. Power densities obtained with cross-linked S-PESTD were superior to those of commercial Nafion $^{\circledR}$, while S-PESB led to comparable values.
\end{abstract}




\section{Introduction}

Proton exchange membrane fuel cell (PEMFC) has been receiving lot of attention as a power source for both stationary and mobile applications, due to its many attractive features [1-4]. PEMFC developed to date require the use of platinum as a catalyst and perfluorinated polymers as membranes. These materials are expensive and platinum is a rare metal and therefore constitute a lock to large-scale development of this clean source of sustainable energy technology. Nafion ${ }^{\circledR}$ membrane is used in PEMFC for its excellent chemical properties and good mechanical stability. Its perfluorinated backbone is resistant to oxidative attack and to degradation. Super-acidic sulfonic acid pending groups are responsible for a good cationic conductivity, in the range of $0.1-0.3 \mathrm{~S} / \mathrm{cm}$ for hydrated protons [5-9].

Several other perfluorinated membranes have been designed for these uses (Flemion ${ }^{\circledR}$ [10], Aquivion ${ }^{\mathbb{B}}$ [11]) with some advantages, like thermal stability, strong water retention, and high proton conductivity. Nevertheless, the main drawback of the perfluorinated membranes is their high cost. Thus, the development of alternative membranes of lower cost and with the same chemical and thermomechanical properties appears as a major challenge.

In recent years, there has been a dramatically growing research activity in the area of ion exchange membrane deriving from aromatic polymers as polyarylethersulfone (PES), polyaryletherketone, polybenzenimidazole, etc. [12-14]. The aromatic ring is usually a favorable site for chemical modification allowing functionalization. Hence, sulfonated polyethersulfone (S-PES) has shown many advantages to elaborate solid electrolyte for PEMFC [14,15], for example, good thermal stability, easy electrophilic substitution. In a former work [16,17], we studied the effect of octylamine grafting on the S-PES backbone (S-PES Octylsulfonamide: S-PESOS) and cross-linking with hexane diamine and amino polyethersulfone ( $\mathrm{HEXCl}, \mathrm{ClNH} 2$ membrane). It was found that the mechanical properties of the obtained membranes are improved as compared with unmodified S-PES.

In this work, we report the results of elaboration of two new S-PES-based membranes. The used starting polymer was chlorosulfonated polyethersulfone $(\mathrm{Cl}-$ PES) with a ratio of pending $\mathrm{SO}_{2} \mathrm{Cl}$ per molecular unit (pmu), a very reactive group, controllable at will. The ratio chosen here was $1.3 \mathrm{pmu}$. Membranes made from hydrolyzed Cl-PES (1.3 group pmu) are fragile and soluble in water when heated. Grafting and/or crosslinking are mandatory for improving mechanical properties and suppressing solubility in hot water. Previous results have been reported by us using octylamine as a grafting reactant and/or PES-NH2 as a cross-linking agent [16]. We report here the use of para isobutyl-phenol as a grafting reagent and 4,7,10-trioxa tridecane-1,13-diamine as a cross-linking reagent.

The hydrophobic character of isobutyl phenol should suppress hot water solubility. The acidic phenol group is easily converted into sodium form, which reacts rapidly and quantitatively with $\mathrm{SO}_{2} \mathrm{Cl}$ groups. We used 0.3 phenate pmu, leaving $1.0 \mathrm{SO}_{2} \mathrm{Cl}$ pmu for obtention of acidic $\mathrm{SO}_{3} \mathrm{H} 1.0$ group pmu after hydrolysis.

4,7,10-Trioxa tridecane-1,13-diamine as a cross-linking reagent should also suppress solubility in hot water. Using an alpha, omega diamine on a poly oxyethylene backbone should keep a convenient inter-chain mobility and decrease the fragility of the membrane. Use of $0,1 \mathrm{M}$ equivalent of this cross-linking reactant keeps 1.1 $\mathrm{SO}_{2} \mathrm{Cl}$ group pmu for $\mathrm{SO}_{3} \mathrm{H}$ production.

The membranes have been characterized, both mechanically and electrochemically, and compared with a commercial membrane. Finally, the fuel cell performances of the membranes have been investigated.

\section{Experimental}

\subsection{Materials}

Nafion ${ }^{\circledR} 117$ membrane was supplied from DuPont. The thickness of Nafion ${ }^{\circledR} 117$ membrane in $\mathrm{H}$-form was $175 \mu \mathrm{m}$ in the dry state and $210 \mu \mathrm{m}$ in wet state.

Petroleum ether, diethyl ether, and tetrahydrofuran were purchased from VWR. Dimethylacetamide (DMAc) was purchased from Acros. Sulfuric acid was purchased from Scharlau. Butylphenol and 4,7,10-trioxa-1,13-tridecandiamine were purchased from Sigma-Aldrich. All chemicals were used without further purification.

Sulfochlorated polyethersulfone, sulfonated polyethersulfone butylsulfonate (S-PESB), and sulfonated polyethersulfone tioxatridecandisulfonamide (S-PESTD) were synthesized in ERAS Labo enterprise.

\subsection{Polymer synthesis}

Cl-PES synthesis was performed in a preceding work by Mabrouk et al. [16].

Polymer grafted with sodium butylphenolate (S-PESB) was prepared with 0.3 equivalent ratio of grafting reactant. The polymer solution is prepared with $20 \mathrm{~g}$ ( $0.034 \mathrm{~mol}$ of monomer unit) of Cl-PES dissolved in $80 \mathrm{~mL}$ of tetrahydrofuran. Sodium butylphenolate is prepared in $20 \mathrm{~mL}$ of anhydrous tetrahydrofuran with butylphenol $(1.57 \mathrm{~g})$ at room temperature and magnetic stirring. $0.301 \mathrm{~g}$ of sodium hydride is added in the solution and kept under argon 
atmosphere at $60^{\circ} \mathrm{C}$. After cooling at room temperature, any solid $(\mathrm{NaCl})$ is filtered off and the solution is poured in $200 \mathrm{~mL}$ of diethyl ether for precipitation. The polymer is filtered out and washed with $\mathrm{H}_{2} \mathrm{SO}_{4}$ (1 $\mathrm{M}$ ) aqueous solution for hydrolysis of residual $\mathrm{SO}_{2} \mathrm{Cl}$. The polymer is then washed with distilled water until the rinsing water keeps neutral. It is finally dried at $80^{\circ} \mathrm{C}$ for $6 \mathrm{~h}$ (Fig. 1). The solid is finally dried at $60^{\circ} \mathrm{C}$ for $2 \mathrm{~h}$. Yield S-PESB $=83 \%$.

Synthesis of S-PESTD polymer is done during the membrane preparation (vide infra).

\subsection{Preparation of membranes}

Two types of membranes were obtained from grafting or cross-linking of Cl-PES.
The preparation of S-PESB membrane was realized by dissolution of powder polymer S-PESB in DMAC (concentration $=1 \mathrm{~g} / 10 \mathrm{~mL}$ ) carried out at room temperature with magnetic stirring.

Fabrication of S-PESTD membrane was done as follows: the cross-linking agent and Cl-PES were dissolved separately at room temperature in DMAc at $10 \%$ and mixed under cooling. The resulting viscous polymer solution was stirred during $15 \mathrm{~min}$ at low temperature (about $5^{\circ} \mathrm{C}$ ) under argon bubbling to remove part of generated $\mathrm{HCl}$. However, only a limited amount of cross-linking occurs at low temperature and the polymer is kept soluble. 0.1 equivalent of cross-linking agent was reacted with Cl-PES groups. Then, the two clear polymer solutions of S-PESB or S-PESTD were filtered through Nylon AG Sefar Nitex

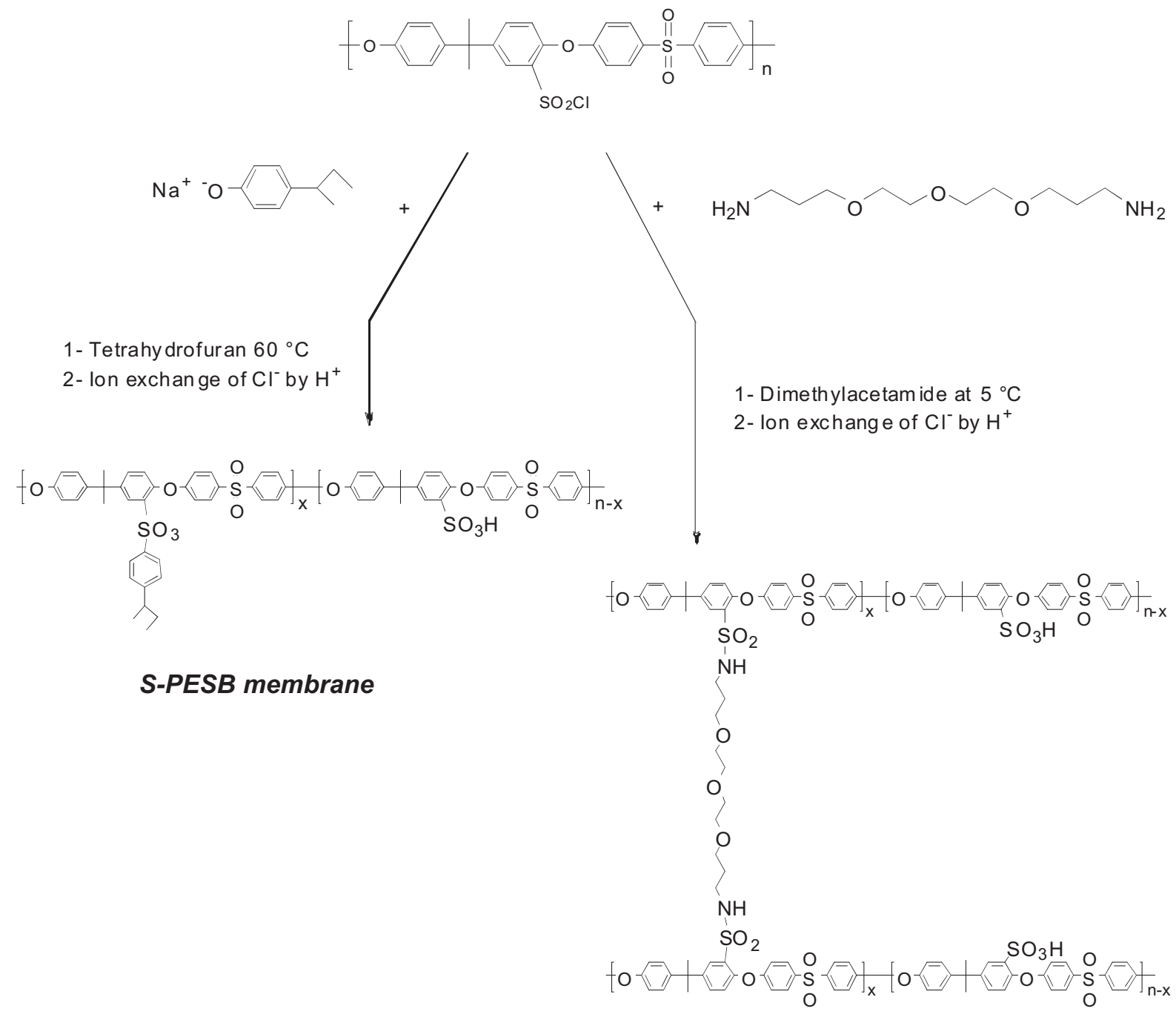

\section{S-PESTD membrane}

Fig. 1. Synthesis of S-PESB and S-PESTD. 
$60 \mu \mathrm{m}$, and the mass recovered were negligible. Then, the polymer solutions were poured in $(30 \mathrm{~cm} \times 18 \mathrm{~cm})$ teflon plate. Drying was carried out, first during $12 \mathrm{~h}$ at $40^{\circ} \mathrm{C}$, then $6 \mathrm{~h}$ at $70^{\circ} \mathrm{C}$, and finally $12 \mathrm{~h}$ at $100{ }^{\circ} \mathrm{C}$. Cross-linking of S-PESTD occurs during heating, the resulting polymer becomes insoluble in usual solvents. After cooling, the membranes were wetted with distilled water, removed from the Teflon plate, and stored wet. Regular thickness was $120 \mu \mathrm{m}$.

\section{Characterization}

\subsection{Water uptake}

Water uptake measurements have been performed after drying membrane samples $(3 \mathrm{~cm} \times 3 \mathrm{~cm})$ at $100^{\circ} \mathrm{C}$ under vacuum overnight. The membrane was weighed $\left(W_{\text {dry }}\right)$ and then immersed in distilled water at room temperature during $48 \mathrm{~h}$ [17]. The membranes were then removed, excess water taken away with an hydrophilic fabric, and the samples were finally weighed $\left(W_{\text {wet }}\right)$. The water uptake was obtained by calculating the percentage of weight gain with respect to the dried membrane weight according to the following equation:

Water uptake $=\frac{\left(W_{\text {wet }}-W_{\text {dry }}\right)}{W_{\text {dry }}} \times 100$

\subsection{Ionic conductivity}

All the membranes were immersed in $1 \mathrm{M} \mathrm{H}_{2} \mathrm{SO}_{4}$ (300 $\mathrm{mL}$ ) for $72 \mathrm{~h}$ before testing. Ionic conductivities of proton exchange membranes were measured at room temperature using a conductimetric clamp in $1 \mathrm{M}$ $\mathrm{H}_{2} \mathrm{SO}_{4}$. The resistances of membranes were measured with a Hameg Instrument Conductimeter LC meter HM8018 [18]. Ionic conductivities $(\mathrm{S} / \mathrm{cm})$ depend on the thickness membrane ( $l$ in $\mathrm{cm}$ ), on the active surface exposed to the membrane $(S=0.785 \mathrm{~cm})$, and on the resistance membrane $\left(R_{\text {membrane }}(\Omega)\right)$. It can be calculated by the following equation.

$\sigma=\frac{l}{R_{\text {membrane }} \cdot S}$

\subsection{Ionic exchange capacity}

The ionic exchange capacity (IEC) has been determined by titration. The membrane in acidic form was immersed for $2 \mathrm{~d}$ in $100 \mathrm{~mL}$ of $10^{-2} \mathrm{M} \mathrm{NaOH}$ aqueous solution. The resulting solution was titrated with
$10^{-3} \mathrm{M} \mathrm{H}_{2} \mathrm{SO}_{4}$ solution [19]. The IEC is expressed as meq of sulfonic groups/g of dry polymer and is determined from the following relation:

$\mathrm{IEC}=\frac{\left(n_{\mathrm{NaOH}}^{i}-n_{\mathrm{NaOH}}^{f}\right)}{W_{\text {dry }}}$

\subsection{Proton transport number}

The cationic transport number was measured using Hittorf Cell: the cell is constituted of two symmetrical glass compartments, each one was filled with aqueous $\mathrm{H}_{2} \mathrm{SO}_{4} 1 \mathrm{M} 50 \mathrm{~mL}$. The membrane $(4.15 \mathrm{~cm})$ is motionlessly placed between them as described in previous papers $[18,20]$.

\subsection{Nuclear magnetic resonance}

The samples of different polymers were dissolved in DMSO d-6 (calibrated: $\delta=2.49$ ppm for the protons) by warming them to ensure a total dissolution of the samples. ${ }^{1} \mathrm{H}$ NMR analyses were performed at a temperature of $21^{\circ} \mathrm{C}$ using a $200 \mathrm{MHz}$ Bruker spectrometer (AC200). Concentrations lower than $40 \mathrm{mg} / \mathrm{mL}$ provide the best resolution.

\subsection{Differential scanning calorimetry}

Differential scanning calorimetry (DSC) measurements were carried out using TA instrument. A sample $(3 \mathrm{mg}$ ) of polymer was put in the cell and the thermogram is registered between 20 and $300^{\circ} \mathrm{C}$ with a sweep rate of $5{ }^{\circ} \mathrm{C} / \mathrm{min}$ under an argon flow of $40 \mathrm{~mL} / \mathrm{min}$. Glass transition temperature $\left(T_{\mathrm{g}}\right)$ was obtained from the second sweep.

\subsection{Dynamical and thermomechanical analysis}

Dynamical and thermomechanical analysis (DTMA) measurements were carried out with TA Instruments DMA Q800 spectrometer working in the tensile mode. Membrane samples were cut with the following dimensions: length $11 \mathrm{~mm}$, width $5 \mathrm{~mm}$, and thickness $120 \mu \mathrm{m}$. Measurements were performed in isochronal conditions $(1 \mathrm{~Hz})$, and the temperature was varied between 5 and $350^{\circ} \mathrm{C}$ at $3{ }^{\circ} \mathrm{C} / \mathrm{min}$ under a dry air flow of $50 \mathrm{~mL} / \mathrm{min}$.

\subsection{Thermal stability}

The thermogravimetric analysis (TGA) was carried out using a Perkin Elmer TGA 6. Approximately $3 \mathrm{mg}$ 
samples were first dried at $100^{\circ} \mathrm{C}$ to remove any moisture and solvent for $8 \mathrm{~h}$, and then programmed from 30 to $400^{\circ} \mathrm{C}$ at a rate of $7{ }^{\circ} \mathrm{C} / \mathrm{min}$ under a $40 \mathrm{~mL} / \mathrm{min}$ nitrogen flow.

\subsection{Membrane electrode assembly}

S-PESB and S-PESTD membranes were immersed in water for $12 \mathrm{~h}$ before assembling in fuel cell. In a membrane electrode assembly (MEA), the membrane was set between the anode and the cathode, both commercially available from Paxitech ${ }^{\circledR}$. The active surface was $5 \mathrm{~cm}^{2}$, and the platinum load was $0.5 \mathrm{mg} / \mathrm{cm}^{2}$. Before assembling, a drop of acidic silica gel was used as a interfacial solution on the active layer to enhance contact between the membrane and the electrodes.

\subsection{Fuel cell measurements}

An elementary Paxitech ${ }^{\circledR}$ fuel cell was used to test the electrode membrane assembly performances $[16,21]$. The measurements were performed with a Voltalab $^{\circledR}$ PGZ301 potentiostat galvanostat, available from Dynamic EIS Voltammetry. The potential is measured as a function of applied current. The current values vary in the range $0-1 \mathrm{~A}$. Hydrogen and oxygen from air were bubbled in distilled water before using in the system. The flow rate was $100 \mathrm{~mL} / \mathrm{min}$. All the experiments were run at room temperature and under atmospheric pressure.

\section{Results and discussion}

\subsection{NMR characterization}

The chemical structure of S-PESB synthesized polymer was determined by ${ }^{1} \mathrm{H}$ NMR. The obtained spectrum is presented in Fig. 2. Peak assignation is the following: $\delta=0.77 \mathrm{ppm}$ is assigned to methyl protons of $-\mathrm{CH}_{2}-\mathrm{CH}_{3}$ (triplet), $\delta=1.1 \mathrm{ppm}$ is assigned to methyl protons of $\mathrm{CH}_{3}-\mathrm{CH}-\mathrm{Ar}$ (doublet), and $\delta \sim 1.4 \mathrm{ppm}$ (bad resolved) is assigned to protons of $\mathrm{CH}_{2}$ group. The signal at $\delta=1.63 \mathrm{ppm}$ is assigned to PES dimethyl group and $\delta=2.5 \mathrm{ppm}$ is assigned to proton of butylphenol tertiary carbon $(-\mathrm{CH}-)$.

The amount of sulfonic acid is given by the ratio areas of signals at $\delta=6.5-8.2 \mathrm{ppm}$ of aromatic protons $[19,21-25]$. The value is in agreement with the value of one sulfonic acid group pmu, as given in Table 1.

Cross-linked S-PESTD is not soluble.

\subsection{Thermal characterization}

The thermal stability of the membranes was investigated by TGA. Fig. 3 shows that both S-PESB and S-PESTD membranes present a very similar behavior and are stable in the temperature range between ambient and approximately $200^{\circ} \mathrm{C}$. Both S-PESB and S-PESTD membranes exhibit steps of weight loss related to the degradation of the sulfonic groups. In comparison, the decomposition of Nafion ${ }^{\circledR}$ sulfonic groups starts at $325^{\circ} \mathrm{C}$. Nevertheless, the thermal stability of all membranes is convenient in the temperature range of fuel cell application.

Results of DSC analysis of S-PESB and S-PESTD membranes are shown in Fig. 4. The glass transition temperatures are, respectively, 185 and $205^{\circ} \mathrm{C}$.

\subsection{Mechanical properties}

DMTA led to curves given in Fig. 5 showing that the storage modulus of the two elaborated membranes remains stable from room temperature to around $180-210^{\circ} \mathrm{C}$. This stability is due to the aromatic

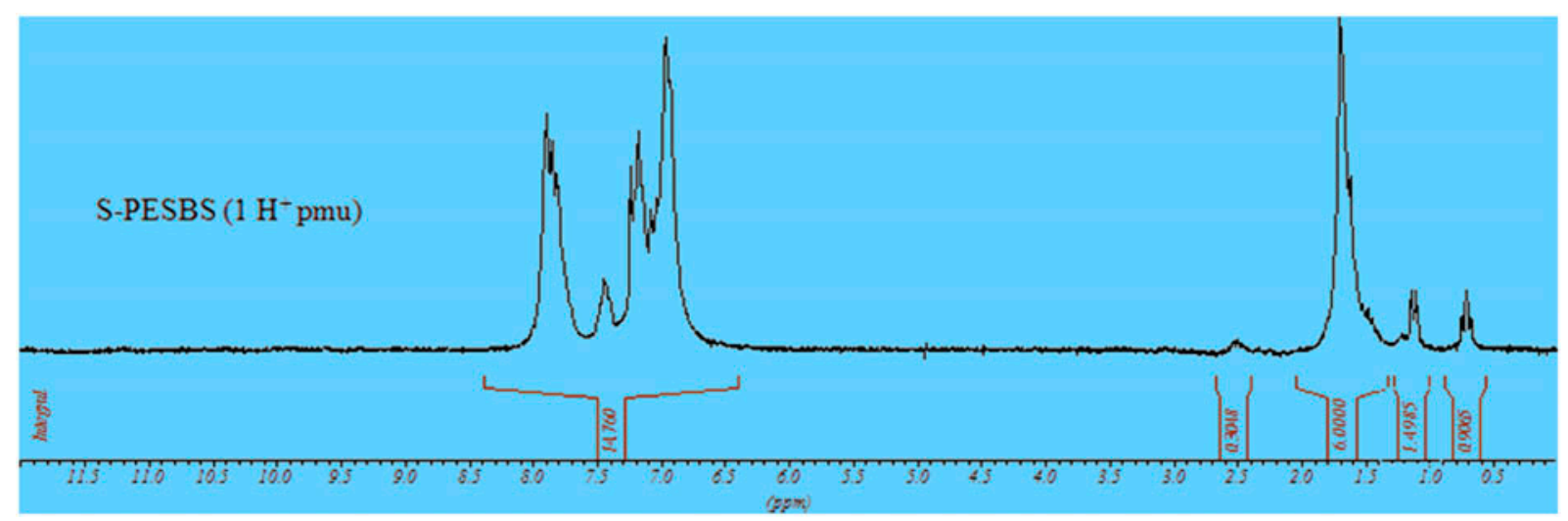

Fig. $2 .{ }^{1} \mathrm{H}$ NMR spectrum of S-PESB, DMSO d6, and $T=20^{\circ} \mathrm{C}$. 
Table 1

Water uptake and IEC of S-PESB, S-PESTD, and Nafion ${ }^{\circledR}$ 117 membranes, surface $=9 \mathrm{~cm}$

\begin{tabular}{llll}
\hline & $\begin{array}{l}\text { Water } \\
\text { Membrake }(\%)\end{array}$ & $\begin{array}{l}\text { Degree of } \\
\text { sulfonation } \\
(\mathrm{pmu})\end{array}$ & $\begin{array}{l}\text { IEC } \\
(\mathrm{meq} / \mathrm{g})\end{array}$ \\
\hline S-PESB & 47 & $1.0 \mathrm{H}^{+}$ & 1.40 \\
S-PESTD & 58 & $1.1 \mathrm{H}^{+}$ & 1.95 \\
Nafion $^{\circledR} 117\left(\mathrm{H}^{+}\right)$ & 32 & $0.9 \mathrm{H}^{+}$ & 1.25 \\
\hline
\end{tabular}

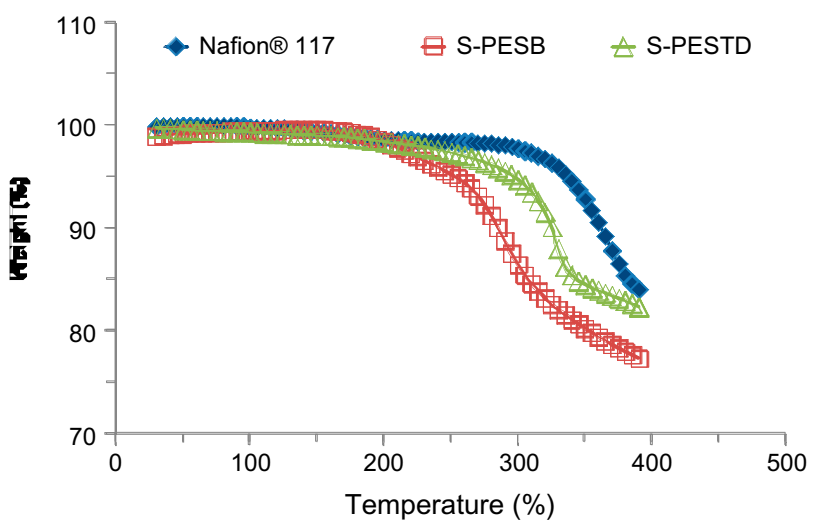

Fig. 3. TGA analysis of S-PESB, S-PESTD, and Nafion ${ }^{\circledR}$ membranes.

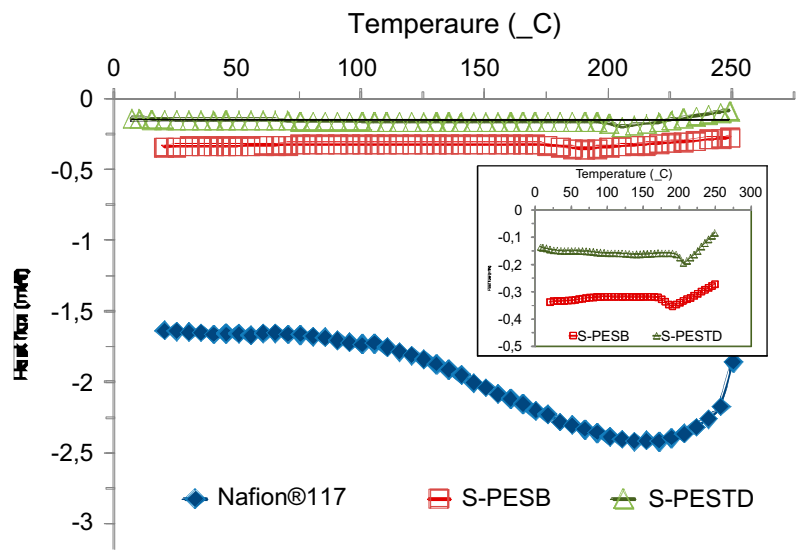

Fig. 4. DSC analysis of S-PESB, S-PESTD, and Nafion ${ }^{\circledR}$ membranes.

backbone of the PES. Evaporation of water observed around $120^{\circ} \mathrm{C}$ leads to a rigid film which becomes more flexible membrane in the range of glass transition temperature. The values of the $T_{\mathrm{g}}$ obtained by DMTA are consistent with those measured by DSC and more precise. The higher $T_{\mathrm{g}}$ of S-PESTD and its

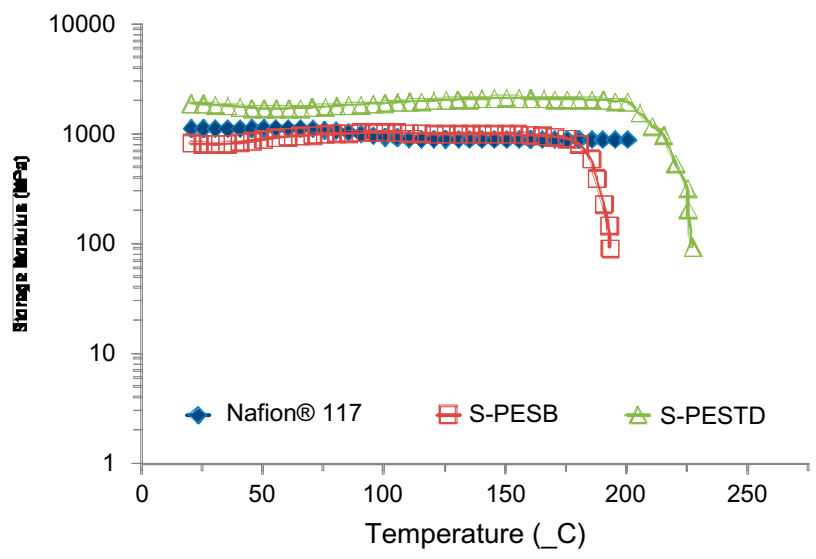

Fig. 5. DMTA curves of S-PESB, S-PESTD, and Nafion ${ }^{\circledR}$ membranes.

greater thermal stability are probably related to the fact that the polymer is cross-linked. Nafion ${ }^{B} 117$ measurement has been made with dehydrated sample.

\subsection{Water uptake}

The values of the water uptake of membranes prepared and commercial Nafion ${ }^{\circledR} 117$ are shown in Table 1, are also given the values of the degree of sulfonation and the IEC of the various membranes. We notice that the water uptake of S-PESB and S-PESTD membranes' values, respectively, 47 and $58 \%$, are higher than Nafion ${ }^{\circledR}$ membrane. These results can be directly correlated with the degree of sulfonation and exchange capacities of the two new membranes that are significantly higher than the Nafion ${ }^{\circledR}$ membrane as shown in Table 1. However, the S-PESB and S-PESTD synthesized membranes exhibit much lower water uptake than that of the unmodified S-PES, of the order of $118 \%$ [12]. This result proves that the grafting and cross-linking decrease the hydrophilic character of the membranes and prevent the polymer from dissolution in water.

\subsection{Ionic conductivity}

Intrinsic values of conductivity should be obtained by impedance measurements at controlled humidity and temperature. But our method gives quickly a good idea of the conductivity and allows comparison between membranes.

Ionic conductivity values of the S-PESB and S-PESTD membranes are of the order of $0.1 \mathrm{~S} / \mathrm{cm}$. They are comparable to that of Nafion ${ }^{\circledR}$. The ionic 
Table 2

Transport number of proton in different membranes. $\left[\mathrm{H}_{2} \mathrm{SO}_{4}\right]=1 \mathrm{M}$

\begin{tabular}{lllll}
\hline & $i(\mathrm{~mA})$ & Time $($ min) & $\mathrm{t}^{+}$cathodic & $\mathrm{t}^{+}$anodic \\
\hline S-PESB membrane & 100 & 188 & 1.00 & 1.00 \\
S-PESB membrane & 70 & 243 & 1.01 & 1.01 \\
S-PESB membrane & 40 & 430 & 1.00 & 0.99 \\
S-PESTD membrane & 100 & 188 & 1.00 & 0.99 \\
S-PESTD membrane & 70 & 243 & 0.99 & 0.99 \\
S-PESTD membrane & 40 & 430 & 1.00 & 1.00 \\
Nafion $^{\circledR} 117\left(\mathrm{H}^{+}\right)$membrane & 100 & 188 & 0.99 & 1.00 \\
Nafion $^{\circledR} 117\left(\mathrm{H}^{+}\right)$membrane & 70 & 243 & 1.00 & 0.99 \\
Nafion $^{(B)} 117\left(\mathrm{H}^{+}\right)$membrane & 40 & 430 & 0.00 & 0.99 \\
\hline
\end{tabular}

conductivity is in fact the sum of two contributions. The first one concerns the intrinsic ionic conduction of the membrane by the $\mathrm{H}^{+}$ions which were counterions, directly associated to negative ionic sites of the membrane. The second kind implies $\mathrm{H}^{+}$ions present in the sulfuric acid phase, absorbed by the membrane. Lower degree of sulfonation affords membranes with significantly lower conductivities [16].

\subsection{Ionic exchange capacity}

IEC values of different synthesized membranes reported in Table 1 can be explained by the corresponding molecular weight and the degree of sulfonation in each membrane. The starting polymer, Cl-PES, has $1,3 \mathrm{SO}_{2} \mathrm{Cl}$ group pmu. For S-PESB, $0.3 \mathrm{SO}_{2} \mathrm{Cl}$ have been reacted with sodium isobutyl phenolate, leaving $1,0 \mathrm{SO}_{2} \mathrm{Cl}$ group pmu, and further hydrolyzed to 1,0 $\mathrm{SO}_{3} \mathrm{H}$ group pmu $\left(1.0 \mathrm{H}^{+}\right.$pmu as titrated). For S-PESTD, $0.2 \mathrm{SO}_{2} \mathrm{Cl}$ group pmu have been reacted with 0,1 mol of 4,7,10-trioxa tridecane-1,13-diamine (2 $\mathrm{NH}_{2}$

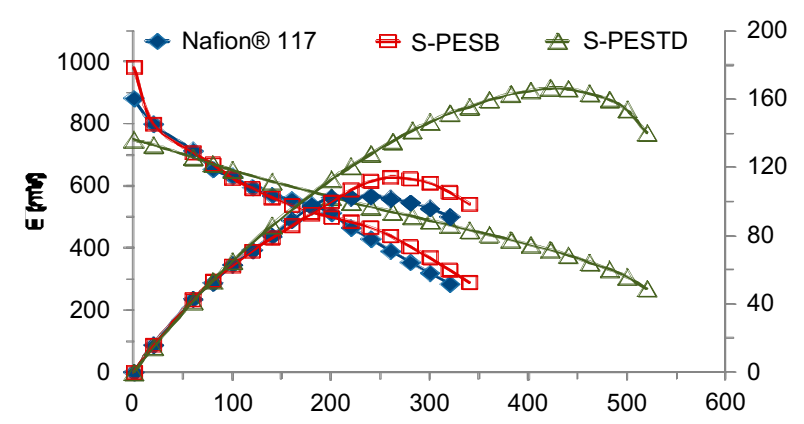

Fig. 6. Polarization and power density curves of PEMFC Paxitech ${ }^{\circledR}$ using S-PESB, S-PESTD, and Nafion ${ }^{\circledR} 117\left(\mathrm{H}^{+}\right)$. Surface $=5 \mathrm{~cm}^{2}, \mathrm{H}_{2}$ flow rates $=70$, and $\mathrm{O}_{2}$ flow rates $=$ $100 \mathrm{~mL} / \mathrm{min}$, at room temperature and atmospheric pressure. groups pmu), leaving 1,1 unreacted $\mathrm{SO}_{2} \mathrm{Cl} \mathrm{pmu}$, and further hydrolyzed to $1.1 \mathrm{SO}_{3} \mathrm{H}$ group pmu as titrated.

\subsection{Protonic transport number}

Proton transport numbers measured with S-PESB, S-PESTD, and Nafion ${ }^{\circledR}$ are reported in Table 2. The measurements were made at different current densities. The resulting values are comprised in the interval: 1.01-0.99 showing a high selectivity of the synthesized membranes toward protons.

\subsection{PEMFC performances}

Performances in PEMFC for the different membranes elaborated are reported in Fig. 6 . The potential in open circuit (OCV) with the different MEAs was in the range $0.9-1 \mathrm{~V}$, which is the same order as that obtained with a Nafion ${ }^{\circledR}$ membrane in the same conditions (OCV at room temperature is usually lower than $1.0 \mathrm{~V})$. It may be noted that, in comparison with the assembly made with the commercial Nafion ${ }^{\circledR}$ membrane, the performances of the assembly fuel cell made with S-PESTD are superior, while the assembly fuel cell with S-PESB membrane gives comparable results. After wetting, the three membranes have similar thickness. The best results of S-PESTD may be related to the fact that the trioxa-decane bridge is more hydrophilic than the isobutyl phenol group.

The fuel cell performances with MEA containing the new prepared membranes are considered to have very promising results in particular that using S-PESTD membrane.

\section{Conclusion}

Unmodified sulfonated polyether sulfone (S-PES) has been suggested as a thermostable material, 
cheaper than perfluorinated material, for fuel cells application. However, membranes made from unmodified S-PES are fragile and soluble in water at high temperature. Modification by grafting hydrophobic groups is easy and improves mechanical properties and the resulting polymer being still soluble in aprotic polar solvents. In order to suppress solubility, crosslinking is mandatory. But cross-linking is known to decrease ionic conductivities and mechanical properties. Cross-linking suppresses solubility, and membrane obtention may be more difficult. So the cross-linking bridge must be carefully chosen. 4,7,10trioxa-1,13-tridecandiamine was chosen as being mechanically flexible and hydrophilic. A procedure was obtained for membrane obtention before crosslinking.

An easy grafting or cross-linking method of Cl-PES with butylphenol or 4,7,10-trioxa-1,13-tridecandiamine reagents for proton-conducting membranes has been proposed. Two non-fluorinated membranes have been fabricated, characterized, and tested in fuel cells. When compared with sulfonated polyethersulfone, the synthesized grafted and cross-linked membranes exhibit improved mechanical properties and a lower hydrophilic character preventing the membrane from dissolution in water. TGA curves show a good stability of the membranes in the temperature range of PEMFC application. DSC measurements and DMTA analysis of the membranes led to glass transition temperatures higher than that of Nafion ${ }^{\circledR}$. Furthermore, the electrochemical measurement showed that the membranes obtained have a conductivity close to that of Nafion ${ }^{\circledR}$ and a high selectivity for the transport of the proton.

The fuel cell performances with MEA containing those membranes are considered to have very promising results. The best results have been obtained with S-PESTD membrane, cross-linked with 4,7,10trioxa-1,13-tridecandiamine reagent, and exhibiting electrochemical performances superior to laboratory cells made from grafted butyl phenol membrane. However, it should be emphasized that S-PESB may be dissolved and the membrane preparation is much easier.

\section{Acknowledgments}

The authors thank the French ANRT (Agence Nationale pour la Recherche et la Technologie) and also the Région Rhône-Alpes for financial support and LEPMI (Laboratoire d'Electrochimie et de Physico Chimie des Matériaux et des Interfaces, St Martin d'hères, 38402 Grenoble, France) for interesting discussions.

\section{References}

[1] S.J. Peighambardoust, S. Rowshanzamir, M. Amjadi, Review of the proton exchange membranes for fuel cell applications, Int. J. Hydrogen Energy 35 (2010) 9349-9384.

[2] Y. Wang, K.S. Chen, J. Mishler, S.C. Cho, X.C. Adroher, A review of polymer electrolyte membrane fuel cells: Technology, applications, and needs on fundamental research, Appl. Energy 88 (2011) 981-1007.

[3] J. Hua, X. Lin, L. Xu, J. Li, M. Ouyang, Bluetooth wireless monitoring, diagnosis and calibration interface for control system of fuel cell bus in olympic demonstration, J. Power Sources 186 (2009) 478-484.

[4] L. Venturelli, P.E. Santangelo, P. Tartarini, Fuel cell systems and traditional technologies. Part II: Experimental study on dynamic behavior of PEMFC in stationary power generation, Appl. Therm. Eng. 29 (2009) 3469-3475.

[5] A. Brunetti, G. Barbieri, E. Drioli, A PEMFC and $\mathrm{H}_{2}$ membrane purification integrated plant, Chem. Eng. Process. Process Intensif. 47 (2008) 1081-1089.

[6] A.G. Hombrados, L. González, M.A. Rubio, W. Agila, E. Villanueva, D. Guinea, E. Chinarro, B. Moreno, J.R. Jurado, Symmetrical electrode mode for PEMFC characterisation using impedance spectroscopy, J. Power Sources 151 (2005) 25-31.

[7] S.M. Haile, Fuel cells materials and components, Acta Mater. 51 (2003) 5981-6000.

[8] V.A. Danilov, M.O. Tade, An alternative way of estimating anodic and cathodic transfer coefficients from PEMFC polarization curves, Chem. Eng. J. 156 (2010) 496-499.

[9] C. Klaysom, B.P. Ladewig, G.Q. Lu, Preparation and characterization of sulfonated polyethersulfone for cation-exchange membranes, J. Membr. Sci. 368 (2011) 48-53.

[10] M. Doyle, G. Rajendran, Perfluorinated membranes, handbook of fuel cells: Fundamentals, technology and applications, in: W. Vielstich, H.A. Gasteiger, A. Lamm (Eds.), Fuel Cell Technology and Applications, vol. 3, Wiley, Chichester, 2003, pp. 351-395.

[11] A. Ghielmi, P. Vaccarono, C. Troglia, V. Arcella, Proton exchange membranes based on the short chain perfluorinated ionomer, J. Membr. Sci. 145 (2005) 108115.

[12] W. Mabrouk, L. Ogier, S. Vidal, C. Sollogoub, F. Matoussi, M. Dachraoui, J.F. Fauvarque, Synthesis and characterization of polymer blends of sulfonated polyethersulfone and sulfonated polyethersulfone octylsulfonamide for PEMFC applications, Fuel Cells 12 (2012) 179-187.

[13] B. Van der Bruggen, Comparison of redox initiated graft polymerisation and sulfonation for hydrophilisation of polyethersulfone nanofiltration membranes, Eur. Polym. J. 45 (2009) 1873-1882.

[14] E.E. Unveren, T. Erdogan, S.S. Çelebi, T.Y. Inan, Role of post-sulfonation of poly(ether ether sulfone) in proton conductivity and chemical stability of its proton exchange membranes for fuel cell, Int. J. Hydrogen Energy 35 (2010) 3736-3744.

[15] L. Li, Sulfonated polyethersulfone cardo membranes for direct methanol fuel cell, J. Membr. Sci. 246 (2005) $167-172$. 
[16] W. Mabrouk, L. Ogier, F. Matoussi, C. Sollogoub, S. Vidal, M. Dachraoui, J.F. Fauvarque, Preparation of new proton exchange membranes using sulfonated poly(ether sulfone) modified by octylamine (SPESOS), Mater. Chem. Phys. 128 (2011) 456-463.

[17] W. Mabrouk, L. Ogier, S. Vidal, C. Sollogoub, F. Matoussi, J.F. Fauvarque, Ion exchange membranes based upon crosslinked sulfonated polyethersulfone for electrochemical applications, J. Membr. Sci. 452 (2014) 263-270.

[18] E. Agel, J. Bouet, J.F. Fauvarque, Characterization and use of anionic membranes for alkaline fuel cells, J. Power Sources 101 (2001) 267-274.

[19] H. Kim, M.-S. Kang, D. Lee, Proton exchange membranes with high cell performance based on Nafion/ poly(p-phenylene vinylene) composite polymer electrolyte, J. Membr. Sci. 304 (2007) 60-64.

[20] C. Sollogoub, A. Guinault, C. Bonnebat, M. Bennjima, L. Akrour, J.F. Fauvarque, L. Ogier, Formation and characterization of crosslinked membranes for alkaline fuel cells, J. Membr. Sci. 335 (2009) 37-42.

[21] C. Iojoiu, F. Chabert, M. Maréchal, N. Kissi, From polymer chemistry to membrane elaboration, J. Power Sources 153 (2006) 198-209.
[22] M. Kameche, F. Xu, C. Innocent, G. Pourcelly, Z. Derriche, Characterisation of Nafion ${ }^{\circledR} 117$ membrane modified chemically with a conducting polymer: An application to the demineralisation of sodium iodide organic solutions, Separ. Purif. Technol. 52 (2007) 497-503.

[23] G.S. Hwang, M. Kaviany, J.T. Gostick, B. Kientiz, A.Z. Weber, M.H. Kim, Role of water states on water uptake and proton transport in Nafion using molecular simulations and bimodal network, Polymer 52 (2011) 2584-2593.

[24] E. Erce Şengül, H. Erdener, R.G. Akay, H. Yücel, N. Baç, İ. Eroğlu, Effects of sulfonated polyetheretherketone (SPEEK) and composite membranes on the proton exchange membrane fuel cell (PEMFC) performance, Int. J. Hydrogen Energy 34 (2009) 4645-4652.

[25] C. Iojoiu, P. Genova-Dimitrova, M. Maréchal, J.Y. Sanchez, Chemical and physicochemical characterizations of ionomers, Electrochim. Acta 51 (2006) 4789-4801. 